\title{
Programmed cell senescence: role of IL-6 in the pituitary
}

\author{
Melanie Sapochnik', Mariana Fuertes ${ }^{1}$ and Eduardo Arzt ${ }^{1,2}$
}

IInstituto de Investigación en Biomedicina de Buenos Aires (IBioBA)-CONICET-Partner Institute of the Max Planck Society, Buenos Aires, Argentina

2Departamento de Fisiología y Biología Molecular y Celular, Facultad de Ciencias Exactas y Naturales, Universidad de Buenos Aires, Buenos Aires, Argentina
Correspondence should be addressed to E Arzt

Email

earzt@ibioba-mpsp-conicet. gov.ar

\begin{abstract}
IL-6 is a pleiotropic cytokine with multiple pathophysiological functions. As a key factor of the senescence secretome, it can not only promote tumorigenesis and cell proliferation but also exert tumor suppressive functions, depending on the cellular context. IL-6, as do other cytokines, plays important roles in the function, growth and neuroendocrine responses of the anterior pituitary gland. The multiple actions of IL-6 on normal and adenomatous pituitary function, cell proliferation, angiogenesis and extracellular matrix remodeling indicate its importance in the regulation of the anterior pituitary. Pituitary tumors are mostly benign adenomas with low mitotic index and rarely became malignant. Premature senescence occurs in slow-growing benign tumors, like pituitary adenomas. The dual role of IL- 6 in senescence and tumorigenesis is well represented in pituitary tumor development, as it has been demonstrated that effects of paracrine IL-6 may allow initial pituitary cell growth, whereas autocrine IL- 6 in the same tumor triggers senescence and restrains aggressive growth and malignant transformation. IL- 6 is instrumental in promotion and maintenance of the senescence program in pituitary adenomas.
\end{abstract}
Key Words
- senescence
- IL-6
- pituitary tumor
- autocrine

\section{Introduction}

Cytokines perform essential roles during infection, cancer and inflammation where they regulate cellular proliferation, differentiation and survival or death (Dranoff 2004, Dinarello 2007).

In particular, interleukin 6 (IL-6) is a multifunctional cytokine that has been implicated in the pathogenesis of a variety of diseases, including cancer (Yao et al. 2014, Hunter \& Jones 2015). In addition, together with other cytokines and factors, IL- 6 has been identified in senescence secretome. However, not all the components of the secretome seem to contribute to the antitumor effects of oncogene-induced senescence (OIS). In fact, the presence of functional protumorigenic and prometastatic factors in the secretome of some senescent cells indicates that they may contribute to tumor progression in a cell in a nonautonomous manner (Coppe et al. 2008a).

The dichotomous role of IL- 6 in senescence and tumorigenesis is well represented in pituitary tumor development. Pituitary tumorigenesis appears to be regulated by extrinsic and intrinsic factors. It has been demonstrated that paracrine IL-6's effects may allow initial pituitary cell growth (required for senescence bypass) (Arzt et al. 1999, Arzt 2001, Graciarena et al. 2004), whereas autocrine IL-6 in the same tumor triggers senescence and restrains aggressive growth and malignant transformation (Sapochnik et al. 2016). 
This review provides an insight into the current understanding of the role of IL-6 in the regulation of pituitary pathogenesis, focusing in the autocrine action of IL-6. Pituitary cell growth regulation by IL-6 reinforces the role of cytokines as factors controlling pituitary cell division, and the findings of the IL-6 role in OIS suggest that endogenous IL- 6 might be involved in the development of pituitary adenoma senescence, which may contribute to explain the benign nature of these frequent tumors.

\section{Biology and functions of IL-6}

IL-6 was first characterized according to its ability to promote the population expansion and activation of $\mathrm{T}$ cells, the maturation of B cells into antibody-producing cells and regulation of the acute-phase response (Klimpel 1980, Yoshizaki et al. 1984, Woloski \& Fuller 1985, Hirano et al. 1986, Andus et al. 1987, Yasukawa et al. 1987, Hirano 2014). However, it is now known that IL-6 affects vascular disease, lipid metabolism, insulin resistance, mitochondrial activities, the neuroendocrine system and neurophysiological behavior (Bethin et al. 2000, McInnes \& Schett 2007, Jones et al. 2011, Rohleder et al. 2012, Schett et al. 2013, Hodes et al. 2014, Kraakman et al. 2015). Accordingly, IL-6 is a pleiotropic cytokine with multiple physiological and pathological functions, produced by almost all stromal cells and cells of the immune system.

The expression of IL- 6 is controlled at multiple levels to prevent overshooting systemic conditions. Several factors have been described as regulators of IL-6 mRNA either at transcriptional or post-transcriptional level. The IL-6 promoter contains motifs for the binding of AP-1, cyclic AMP, C/EBP $\beta$, Sp1, CREB, STAT3 and NF- $\mathrm{BB}$ (Lee et al. 1987, Matsusaka et al. 1993, Kishimoto 2005, Gerlo et al. 2008, Spooren et al. 2010). IL-6 transcript is positively regulated by Arid 5a (Masuda et al. 2013), TNF $\alpha$ and IL-1 $\beta$ (Gruys et al. 2005), and negatively regulated by regnase-I (Iwasaki et al. 2011), bromodomain-containing protein 4 (BRD4) (Barrett et al. 2014), and microRNAs (miRs) e.g. miR-26a (Yang et al. 2013), miR-142 (Sun et al. 2013), miR-146a (He et al. 2014), miR-146b (Xiang et al. 2014), miR-187 (Rossato et al. 2012), miR-200s (Dou et al. 2013) and miR-329 (Garg et al. 2013) (Fig. 1).

IL-6 is a glycosylated secreted protein of nearly $25 \mathrm{kDa}$, which varies depending on different N-linked glycosylation and species. Although not necessary for its function, IL- 6 glycosylation might be important for stability or half-life of the protein. It has a characteristic structure made up of four long alpha-helices, which are arranged in a way that leads to an up-downdown topology found in all IL-6 type cytokines (Scheller et al. 2011).

The secretion and availability of IL- 6 is ubiquitous, and it can bind to various types of cells in different tissues. IL- 6 acts on cells as a dimer by binding to a specific IL- 6 receptor (IL-6R) complex composed of two IL-6R $\alpha$ chains (also known as IL-6R $\alpha$, gp80 or CD126) and the resultant IL-6/IL-6R $\alpha$ complex associates with two signal-generating receptor beta chain subunits, named gp130 (also known as IL-6R $\beta$ or CD130), at three distinct receptor-binding sites (Kojima et al. 2013). In contrast to gp130, IL-6Ro is only expressed on a limited number of cell types, which actually facilitates the selective activation of several target cells (Rose-John et al. 2006, Scheller \& Rose-John 2006). Upon binding to the receptor and gp130, IL-6 induces various functions by activating cell signaling events (Mihara et al. 2012). IL-6 triggers signal transduction via two different pathways (Kumari et al. 2016) (Fig. 1). The classic signaling, in which IL-6 binds to its transmembrane $80 \mathrm{kDa}$ receptor IL-6R $\alpha$, and the trans-signaling in which IL- 6 binds to the soluble secretory form of IL-6R $\alpha$ (sIL-6R $\alpha$ ) to form a complex that increases the circulating halflife of IL-6 and promotes its bioavailability (Rose-John \& Heinrich 1994, Peters et al. 1996). In both cases, once IL-6 binds to the receptor (with the same affinity), the complex binds to transmembrane gp130. As gp130 is ubiquitously expressed, IL-6R expression determines whether a cell is responsive to classic signaling or trans-signaling. Although most soluble receptors are antagonist and compete with their transmembrane receptor, sIL-6R $\alpha$ is an agonist of IL-6R $\alpha$ (Wolf et al. 2014). Classical IL-6R signaling seems to control central homeostatic processes (regulation of the neuroendocrine system), activates anti-inflammatory pathways and promotes the regeneration of tissue, whereas IL-6 trans-signaling activates proinflammatory pathways and plays an important role in many diseases and cancer (Wolf et al. 2014, Kumari et al. 2016). sIL$6 \mathrm{R} \alpha$ is generated by alternative splicing of IL-6 mRNA or by 'shedding', a limited proteolysis of extracellular region of the membrane-bound IL-6R carried out by transmembrane zinc-dependent proteases ADAM17 and ADAM10 (Yoshida et al. 1996, Jones et al. 2001, 2011, Chalaris et al. 2011). Like sIL-6R $\alpha$, a soluble form of gp130 (sgp130), is also present in circulation at relatively high concentrations during inflammation and cancer (Kovacs 2001, McFarland-Mancini et al. 2010, Rose-John 2012). Although classic signaling is not affected by sgp130, trans-signaling is inhibited by sgp130 binding to the IL-6-sIL-6R complex.

Published by Bioscientifica Ltd 


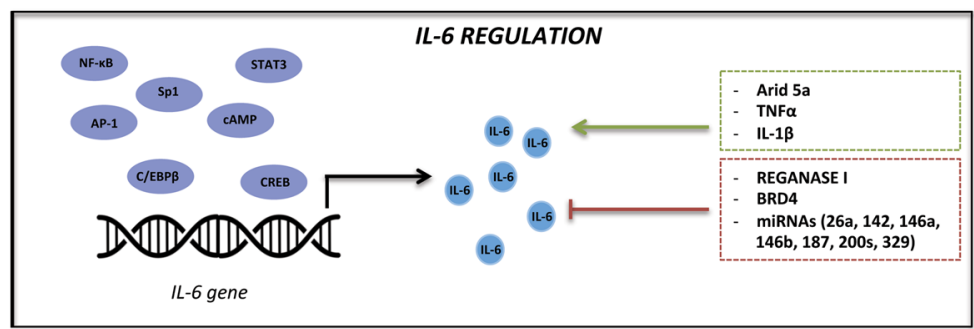

IL-6 SIGNALING

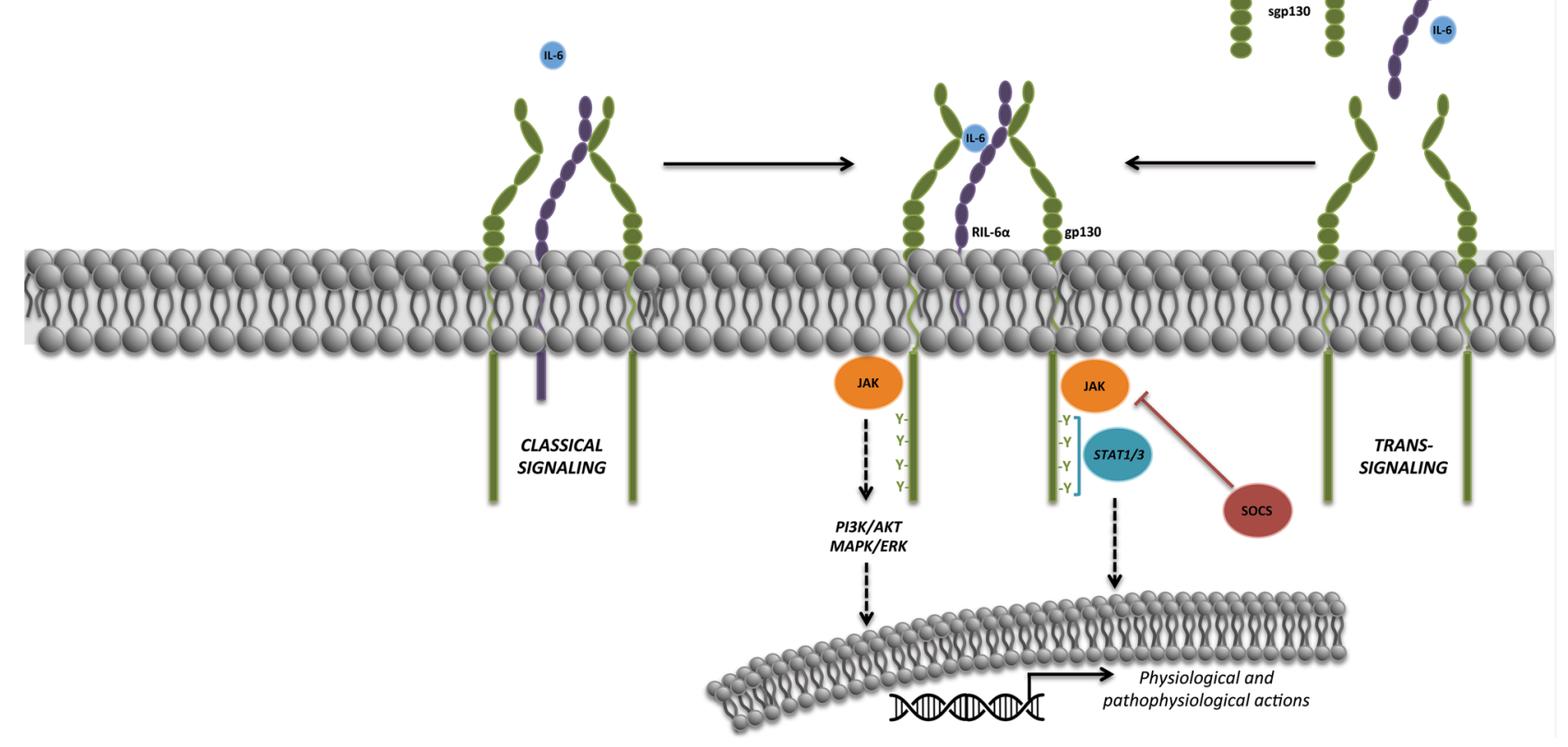

Figure 1

IL-6 regulation and signaling. IL-6 expression and function is highly regulated by many factors that act at a transcriptional and posttranslational level. IL- 6 binds to its receptor and then forms a heterotrimer with two gp130 subunits anchored to the plasma membrane. IL-6 signals by two different pathways: classic IL-6 signaling is mediated via the membrane-bound IL-6R (left), whereas trans-signaling acts via sIL-6R (right). Dimerization of gp130 results in the activation of STAT1/3, MAPK/ERK and PI3K/AKT signaling pathways, which regulates different physiological and pathophysiological processes.

Once IL-6-IL-6R complex is formed, JAK kinases go through a conformational change, bringing the two JAKs close enough to phosphorylate each other and became activated. Signal transducer and activator of transcription 3 (STAT3) and STAT1 are recruited to the phosphorylated YXXQ motifs in gp130 and phosphorylated by JAK kinases, at the Y705 and Y701 tyrosine residues, for STAT3 and STAT1, respectively (Hirano et al. 1997, 2000). The activated STAT3 and STAT1 dimerize with each other, making STAT3 or STAT1 homodimers and STAT3/ STAT1 heterodimers. These activated STAT dimers enter the nucleus and bind to the specific DNA sequences in the regulatory regions of their target genes (Darnell 1997). STAT3 plays multiple roles depending on the cell context. The involvement of STAT3 in proliferation and cell survival by activating $c-m y c$, cyclin D1, bcl2, bclxl or mcl1 (Hirano et al. 1997, 2000), in tumorigenesis (Bowman et al. 2000, Yu et al. 2009) and in growth arrest and differentiation is well described (Nakajima et al. 1996, Hirano et al. 1997, 2000). To prevent overstimulation, the mechanism to turn off cytokine-mediated signal transduction involves Src-homology 2 domain-containing phosphatase (SHP2), which induce desphophorylation of JAK, gp130 and STATs (Lehmann et al. 2003); protein inhibitors of activated STATs (PIAS) that inhibit STAT1 signaling by the interaction with the DNA binding of activated STAT1 (Liu et al. 1998); and suppressor of cytokine signaling (SOCS), which acts as classical feedback inhibitor acting on the JAKs and thereby inhibit the phosphorylation of gp130, STATs and JAKs themselves (Naka et al. 1997, Starr et al. 1997). Although JAK/STAT is the most described IL-6 signaling pathway, there are two other major pathways activated by IL-6: mitogenactivated protein kinase (MAPK)-extracellular signalregulated kinase (ERK) and phosphatidyl-inositol-3-kinase (PI3K)-AKT pathways (Heinrich et al. 2003) (Fig. 1). 


\section{The dual action of IL-6: tumor vs senescence}

Cellular senescence is now recognized as a potent tumor suppressive mechanism that arrests the growth of cells at risk for malignant transformation (Braig et al. 2005, Chen et al. 2005, Collado et al. 2005, Michaloglou et al. 2005, Narita \& Lowe 2005, Courtois-Cox et al. 2006, Ventura et al. 2007, Xue et al. 2007). Recent studies show that senescent cells develop altered secretory activities, i.e. secrete proinflammatory cytokines, proteases and other proteins, that may induce changes in the tissue microenvironment, relaxing its control over cell behavior and promoting tumorigenesis (Krtolica et al. 2001, Acosta et al. 2008, Coppe et al. 2008a,b, Green 2008, Kuilman et al. 2008).

The senescent phenotype is not limited to an arrest of cell proliferation. In fact, a senescent cell is a potentially persisting cell that is metabolically active and has undergone widespread changes in protein expression and secretion, ultimately developing the senescenceassociated secretory phenotype (SASP). Proliferating cells enter senescence in response to physiological signals during embryonic patterning and organogenesis, pathophysiological signals related to aging or imminent malignant transformations or exogenous causes of damage (Muñoz-Espín \& Serrano 2014). The SASP includes several families of soluble and insoluble factors. These factors can affect the surrounding cells by activating various cellsurface receptors and corresponding signal transduction pathways that may lead to multiple pathologies, including cancer. However, the role of SASP in tumor progression remains unclear and can be beneficial or deleterious, depending on the biological context (Lecot et al. 2016). Senescence is a delayed stress response involving multiple effector mechanisms and has been recently described not only as a static endpoint but also as a dynamic process of phenotypic establishment (Baker \& Sedivy 2013, Young et al. 2013). This distinction becomes more relevant in acute types of senescence, such as OIS, where the initial phenotype of OIS is a highly proliferative state, which mimics transformation, but this mitotic burst is gradually replaced by senescence (Young et al. 2009).

In particular, it has been shown that OIS is specifically linked to the activation of an inflammatory transcriptome, including pleiotropic cytokine IL-6 (Coppe et al. 2008a, 2010, Kuilman \& Peeper 2009). IL-6 has been identified as a key component of the senescence secretome, which enables senescent cells to communicate with their microenvironment. The role of IL- 6 and other SASP factors could support tumorigenesis and cell proliferation, but also may exert tumor suppressive functions and trigger an immune response, thereby favoring tumor cell clearance and cancer regression (Cichowski \& Hahn 2008). Certainly, the secretory profile and function of the SASP are highly dependent on the cell type and context. Besides its paracrine mitogenic action, IL- 6 was shown to actively contribute to the senescence process by reinforcing cell-cycle arrest in an autocrine feedback loop: is required for the execution of OIS in a cell-autonomous mode (Kuilman et al. 2008, Sapochnik et al. 2016). IL-6 depletion causes the inflammatory network to collapse and abolishes senescence entry and maintenance. This may suggest that IL-6 pools required for OIS and for promoting oncogenicity or cell proliferation (Sparmann \& Bar-Sagi 2004, Ancrile et al. 2007) are inherently different.

It was suggested that the nature of the IL- 6 target cell decides whether IL- 6 acts as tumor suppressor or promoter (Kuilman et al. 2008, Yun et al. 2012). The genetic makeup of the IL- 6 target cell, whether normal or transformed, could contribute to specifying the biological response to IL-6.

\section{Pathophysiological role of IL-6 in the pituitary}

In the adenohypophysis, hypothalamic stimulatory and inhibitory factors, together with feedback signals derived from target organs, converge with the auto-/ paracrine factors, to induce transcriptional regulation, translation and secretion of the pituitary hormones. Collectively, these regulatory mechanisms manage an accurate and dynamic gland homeostatic process (PerezCastro et al. 2012).

The physiological importance of the role that cytokines play in modulating the neuroendocrineimmune interconnection is extensively reflected in the anterior pituitary gland (Arzt et al. 1999, PerezCastro et al. 2012). The gp130 cytokines of the IL-6 family constitute a well-known example as they play important roles in function, growth and neuroendocrine responses of the gland. The expression of specific receptors for the different gp130 cytokines, as well as the cytokines themselves, is expressed in the anterior pituitary cells, providing a basis for the regulation of hormone secretion and cell growth. During acute or chronic inflammation or infection, systemic, hypothalamic or hypophyseal gp130 cytokines may act on anterior pituitary cells, integrating the neuroendocrine response. Elevated levels of cytokines alter the physiological hormone production to adapt the

Published by Bioscientifica Ltd. 
endocrine system to the needs of the organism to respond adequately to pathogens.

Pituitary tumors are mostly benign, non-metastatic and monoclonal neoplasms constituted by cells of the adeno-pituitary gland, which generally cause small lesions and present a slow growth (Scheithauer et al. 2006, Dworakowska \& Grossman 2009, Melmed 2011, 2015, Lake et al. 2013, Kopczak et al. 2014). The pathophysiological consequences of a pituitary adenoma are related to overproduction of particular pituitary hormones or due to tumor compression and damage to the normal pituitary and vital structures surrounding it (Yu \& Melmed 2010).

Multiple extracellular and intracellular signals determine pituitary cell proliferation. Changes in the expression or function of several cytokines and growth factors have been described to participate in pituitary adenoma development (Perez-Castro et al. 2012), as it is well known that normal pituitary cells are under the auto/paracrine action of these factors. Altered levels of transforming growth factor alpha and beta protein families, epidermal growth factor, fibroblast growth factor family, bone morphogenetic protein 4 and IL-6/ gp130 family, have been observed in pituitary tumors (Jones et al. 1994, Perez Castro et al. 2000, Paez-Pereda et al. 2003, Dworakowska \& Grossman 2012, Perez-Castro et al. 2012, Jiang \& Zhang 2013). It was described that matrix metalloproteinase, secreted by pituitary cells, contribute to the control of cell proliferation during tumorigenesis also (Paez-Pereda et al. 2005).

In particular, the putative oncogenic role of the gp130 protein has been demonstrated in lactosomatotroph GH3 tumor cells, which do not develop into tumors in nude mice after gp130 downregulation, indicating that one or more of the gp130 cytokines might play a role in pituitary tumorigenesis (Castro et al. 2003). The expression of almost all of the gp130 cytokines and their corresponding receptors was detected either in normal or tumoral pituitary (Jones et al. 1994, Hanisch et al. 2000, Perez Castro et al. 2001).

Pituitary tumors do not progress like other solid tumors, which start with hyperplasia, pass a state of benign adenoma and end up with an aggressive carcinoma (Farrell \& Clayton 1998, Melmed 2008, Colao et al. 2010). Pituitary cells are among the few epithelial cell types that rarely undergo malignant transformation. Given that premature senescence occurs in slow-growing benign or early-stage tumors but not in late stage or malignant tumors and that pituitary adenomas have exhibited stable growth after decades of observation (Levy \& Lightman 2003, Melmed 2011), the unique growth of these benign adenomas has been linked with this tumor suppressive mechanism. OIS has been implicated in the arrest of pituitary tumors as in several other types of benign tumors. It has been shown in human and murine melanocytic nevi (Michaloglou et al. 2005, Goel et al. 2009), human dermal neurofibromas (Courtois-Cox et al. 2006), human Schawnnomas (Simonetti et al. 2014) and human pituitary adenomas (Lazzerini Denchi \& Helin 2005, Donangelo et al. 2006, Chesnokova et al. 2007, 2008, Alexandraki et al. 2012, Sapochnik et al. 2016), but not in malignant adenocarcinomas. Cell senescence has a functional relevance in vivo, as a physiological mechanism limiting tumorigenesis in many diseases. Premature pituitary tumor cell senescence appears to bypass pro-proliferative signals, thereby stopping cell proliferation, while preserving vital homeostatic pituitary functions in order to maintain cell viability (Arzt et al. 2009, Melmed 2011).

IL-6 is produced by tumoral cells themselves but is also delivered to the adenoma cells through IL-6producing folliculo stellate (FS) cells, which surround or invade the pituitary tumors (Hofler et al. 1984, Farnoud et al. 1994, Ueta et al. 1995, Renner et al. 1997, 1998, Vajtai et al. 2007). IL-6 mRNA and protein levels were also detected in cell cultures of all types of pituitary adenomas (Jones et al. 1994, Arzt et al. 1999, Borg et al. 2003, Sapochnik et al. 2016). Pituitary IL-6 production can be increased by many compounds such as IL-1 (Spangelo et al. 1991), TNF $\alpha$, pituitary adenylate cyclase-activating polypeptide (Arzt et al. 1999) and by lipopolysaccharides (Tichomirowa et al. 2005), and it is inhibited by glucocorticoids (Pereda et al. 2000). Intrapituitary IL-6, regulated both by neuroendocrine and the immune system, plays a critical role in the pituitary as a neuroendocrine-immune integrator.

Paracrine IL-6 promotes the growth of pituitary cells that could lead to the development of pituitary adenomas. It acts as a stimulatory growth factor (Arzt et al. 1999, Arzt 2001) and also promotes the secretion of vascular endothelial growth factor and matrix metalloproteinases from surrounding FS cells (Renner et al. 1998, Gloddek et al. 1999), producing not only the expansion of tumoral cells but also vessel formation and extracellular matrix remodeling (Renner et al. 1998). Notably, although this cytokine induced proliferation of GH3 lactosomatotroph cells, it was also shown to inhibit normal pituitary cells (Arzt et al. 1993). Inhibitory or stimulatory actions of

Published by Bioscientifica Ltd 
IL-6 were observed in ACTH-, PRL-, GH-secreting and nonfunctioning adenomas, without association to the size or type of the tumor (Pereda et al. 1996). Activation of different signaling pathways by IL-6/gp130 complex, as discussed previously, may explain the differences observed in IL-6 action on the anterior pituitary (Arzt 2001).

\section{Autocrine IL-6 mediates pituitary tumor senescence}

Different mechanisms and factors involved in the initiation and progression of pituitary adenomas have been described, including cell-cycle deregulation, overexpression of growth factors, oncogenes and hormones, defective signaling pathways and an altered intrapituitary microenvironment (Clayton \& Farrell 2004, Farrell 2006, Dworakowska \& Grossman 2009, Colao et al. 2010, Vandeva et al. 2010, Melmed 2011, Perez-Castro et al. 2012), as well as inherited or somatic mutations in genes such as AIP (Vierimaa et al. 2006), GPR101 (Trivellin et al. 2014) and USP8 (Reincke et al. 2015). The recent characterization of pituitary stem cells (Fauquier et al. 2008, Garcia-Lavandeira et al. 2009, 2015, Vankelecom \& Gremeaux 2010) implies the possibility of defining their mechanisms involved not only in pituitary cell renewal but also in pituitary tumorigenesis. Several groups have described the presence within the pituitary tumor of a side population containing cells with high efflux capacity and enriched with potentially tumor stem cells (Gleiberman et al. 2008, Florio 2011, Mertens et al. 2015). In line with that, enhanced selfrenewal as a mechanism of tumor initiation has been reported in pituitary adenomas (Hosoyama et al. 2010, Gaston-Massuet et al. 2011, Andoniadou et al. 2013, Donangelo et al. 2014). It has been proposed that the initial mutation that drives tumorigenesis occurs in a cell type (adult pituitary stem cells, SCs) that does not contribute cell autonomously to the tumor. SCs cells, which include FS, secrete factors (such as IL-6) leading to the transformation and proliferation of neighboring cells that generate a tumor (Andoniadou et al. 2013).

FS cells are major agranular cells with a characteristic star-shaped morphology located in the parenchymal tissue of the anterior pituitary gland, representing $5-10 \%$ of all pituitary cells. Within the pituitary, FS cells form a three-dimensional anatomical cellular network surrounding hormone-secreting cells, connected to them via gap junctions (Renner et al. 1998). In the normal pituitary, IL-6 is produced only by FS cells
(Vankelecom et al. 1989), whereas in pituitary adenomas, IL-6 is produced by the pituitary tumor cells themselves (Jones et al. 1994). Intrapituitary IL-6 is assumed to act in a paracrine manner to modulate endocrine cell function and growth in response to external stimuli. IL-6 itself influences hormonal output, i.e. stimulates the secretion of ACTH, GH, PRL, LH and FSH (Renner et al. 1996, Ray $\&$ Melmed 1997), from the anterior lobe in a paracrine manner. A transition zone between normal pituitary tissue and the adenoma that is extremely rich in FS cells has been demonstrated (Farnoud et al. 1994). Paracrine IL-6 delivered by FS cells contributes to the development of an adenoma, by promoting tumor cell expansion because of the induction of VEGF release and extracellular matrix-modifying enzymes and tissue inhibitors of metalloproteinases expression (Matsumoto et al. 1993), which cause extracellular matrix remodeling and vessel formation (Renner et al. 1998). After transformation of a normal pituitary cell to a tumoral cell, the further development of the tumor is triggered by the interaction of the FS cells and the tumor cells. In vitro studies have shown additional evidence of this. The rat somatotrophic pituitary MtT/S cells overexpressing (sense) or lacking (antisense) gp130 protein were coinoculated with the TtT/GF cell, a mouse FS-like cell line, in nude mice (Graciarena et al. 2004). At low cell concentration, MtT/S sense and control clones generated tumors of a smaller size than those derived from these same clones plus TtT/GF cells, showing a clear dependence on FS cells. In both cases, MtT/S antisense had an impaired tumor development. Moreover, vessel density was significantly lower in tumors derived from MtT/S antisense plus TtT/GF cells (Graciarena et al. 2004). In these interactive processes, paracrine IL-6 plays a prominent role by stimulating tumor cell proliferation, tumor neovascularization and extracellular matrix remodeling.

OIS is linked specifically to the activation of an inflammatory transcriptome, which includes IL-6, in a transduced human melanocytes model (Kuilman et al. 2008). Upon secretion by senescent cells, IL- 6 acts promitogenically in a paracrine fashion, but regulates OIS in a cell-autonomous mode, indicating that IL-6 can function as an autocrine or paracrine tumorigenic factor. In line with that, oncogenic stress also triggered the induction of the CDK inhibitor p15 INK4b, which was dependent on the presence of both IL- 6 and C/EBP $\beta$. Taking into account that the stable proliferative arrest in G1 phase of the cell cycle characteristic of senescence is through activation of the $\mathrm{p} 53 / \mathrm{p} 21^{\mathrm{Cip} 1}$ and $\mathrm{pRb} / \mathrm{p} 16^{\text {INK4a }}$ pathways and, consequently, overexpression of cdk

Published by Bioscientifica Ltd 
inhibitors like $\mathrm{p} 15^{\text {INK4b; }}$ this result establishes a link between OIS-activated interleukin signaling and the cell-cycle machinery, suggesting that IL-6 acts in concert with its receptor and $\mathrm{p} 15^{\mathrm{INK} 4 \mathrm{~b}}$ to cause cell-cycle arrest in response to oncogenic stress. Thus, IL- 6 not only triggers OIS but also maintains it (Kuilman et al. 2008). The protective role of IL-6 in OIS, as discussed below, occurs naturally in pituitary adenomas as a dynamic and slow mechanism, which results in a benign tumor with stable growth arrest. Interestingly, in other endocrine tumors like thyroid nodules, IL-6 (and its receptor) expression (Ruggeri et al. 2002) and also OIS with an associated inflammatory secretome (Vizioli et al. 2014) has been reported, suggesting that a senescence process involving IL-6 might also take place in thyroid tumor progression.

The activation of cell-cycle arrest machinery and the involvement of PTTG (Chesnokova et al. 2007, 2008) was also found in pituitary adenomas and more interestingly, a differential lineage-specific pathway restricting and controlling pituitary cell-cycle progression and triggering senescence was described (Chesnokova et al. 2011). PTTG exhibits oncogene properties (Pei \& Melmed 1997, Zhang et al. 1999) and its expression results in the activation of DNA-damage signaling pathways, aneuploidy and chromosomal instability in vitro and in vivo (Kim et al. 2005, 2007, Vlotides et al. 2007), ending in pituitaryspecific senescent features (Chesnokova et al. 2005, 2007). Different from most human GH-producing pituitary adenomas in which PTTG overexpression is associated with p21-dependent senescence (Chesnokova et al. 2008), tumors arising from the gonadotroph lineage also exhibit high PTTG levels, but p21 is not expressed in gonadotrophderived nonfunctioning pituitary adenomas, which express $\mathrm{p} 15^{\mathrm{INK} 4 \mathrm{~b}}$ and $\mathrm{p} 16^{\mathrm{INK} 4 \mathrm{a}}$. This could be explained by

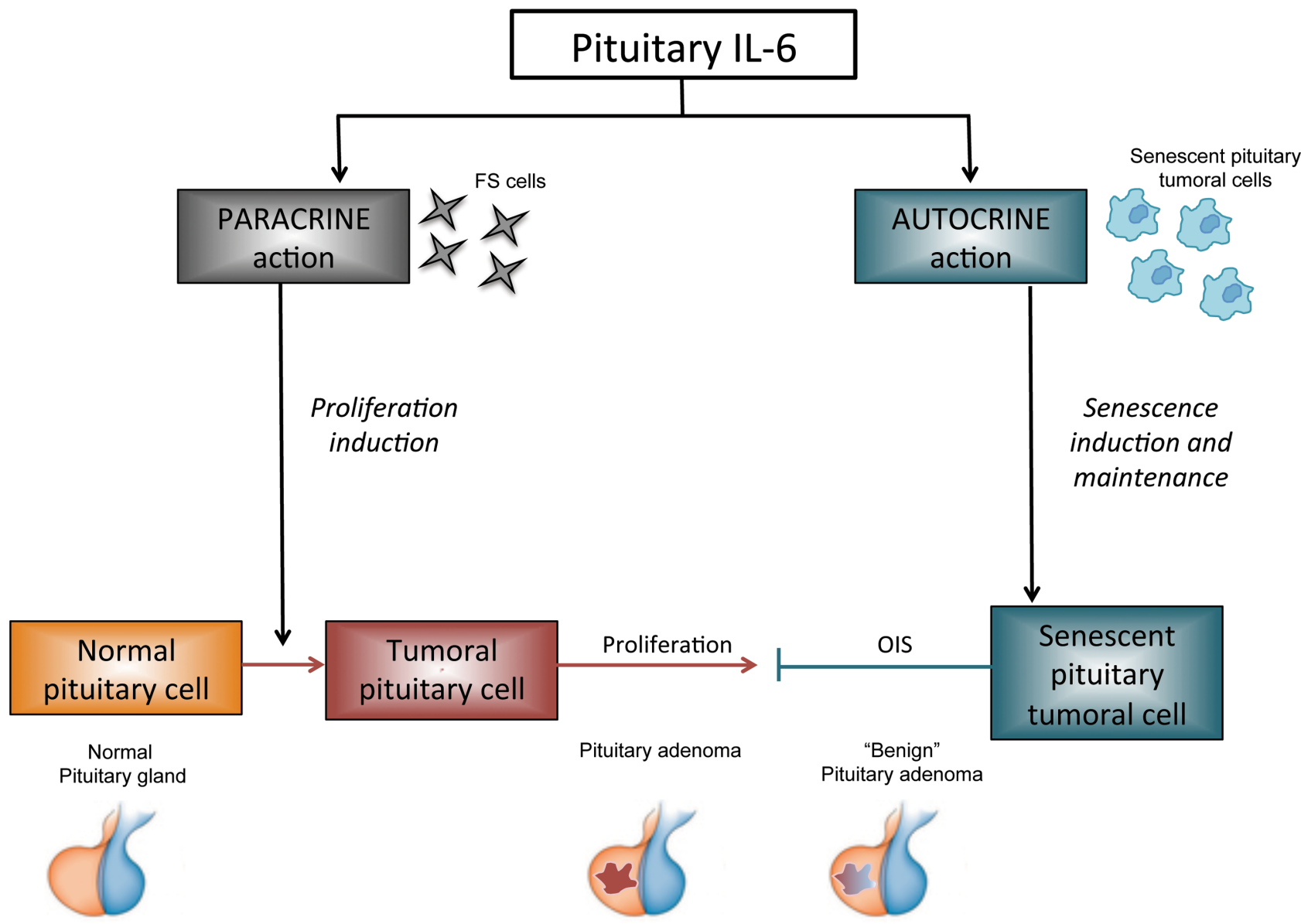

Figure 2

Pathophysiological role of IL-6 in the pituitary: role of autocrine IL- 6 in senescence. IL- 6 has a dual role in the anterior pituitary. It is secreted to the normal or adenoma cells by FS cells which, by its paracrine action, induce pituitary cell proliferation at the initial proliferative phase of pituitary adenomas. IL- 6 is also secreted by the tumoral cells themselves which, by its autocrine action, stops proliferation and progression of pituitary tumors by inducing and maintaining senescence.

http://jme.endocrinology-journals.org DOI: $10.1530 / \mathrm{JME}-17-0026$
(C) 2017 Society for Endocrinology Printed in Great Britain
Published by Bioscientifica Ltd 
the fact that activation of senescence effector pathways depends on cell and tissue context, the intensity and duration of the signal and the nature of the damage (d'Adda di Fagagna 2008), which has led to define distinct senescence types (Muñoz-Espín \& Serrano 2014).

A recent work (Zhang et al. 2015) has shown that the expression of IL-6 was significantly increased in aging pituitary tissues, i.e. senescent pituitary, in contrast to normal and tumoral rat pituitaries. Plasma IL-6 concentration was decreased in aging rats compared with normal rats, indicating that the paracrine activity of IL-6 was inhibited in aging rats. As discussed previously, IL-6 has opposite dual effects on cell proliferation and growth (Arzt et al. 1993, 1999, Renner et al. 1996). Taking into account that IL-6 participates in the progression of pituitary tumors, and its role in OIS, this cytokine appears as a candidate for an autocrine/paracrine regulator of pituitary adenoma control. The regulation of OIS by IL- 6 has been recently shown using a pituitary tumor senescence cell model (MtT/S cell line) and an in vivo senescence model in human pituitary tumor samples (Sapochnik et al. 2016). In both models, the absence of endogenous IL- 6 produces a decrease in senescent biomarkers and, as expected, an increase in cell proliferation and invasion capacity. These findings indicate that the lack of IL-6 allowed tumoral cells to bypass senescence and consequently become tumorigenic. In pituitary tumors, IL-6 contributes to maintain the senescent phenotype of these tumoral cells by its autocrine action. Comparing tumors developed by the silencing of IL-6 (i.e. the abolishment of senescence) with tumors resembling the natural situation in which both the paracrine proliferative IL- 6 and the autocrineinducing senescence are on, tumors expressing endogenous IL-6 present a more pronounced senescent phenotype. The dual action of IL- 6 in the regulation of two opposite mechanisms occurs in different steps of pituitary tumor development (Fig. 2). In the normal pituitary, paracrine IL-6 delivered by FS cells do not affect normal cell growth but may act to induce proliferation of tumoral cell and, consequently, the development of an adenoma (Fig. 2). However, autocrine IL-6 in the same tumor may induce and maintain senescence and contribute to control aggressive growth and malignant development of these cells (Fig. 2).

\section{Future perspectives}

Senescence is considered an important tumor protection barrier that contributes to stop proliferation and further malignant transformation allowing the pituitary cell to remain viable and perform its homeostatic physiological function. The presence of senescent cells in the tumor and the consequently produced SASP are important to sustain the vital functioning of the pituitary gland and its homeostasis role. Thus, pituitary adenomas constitute faithful in vivo models of senescence. The presence of senescent cells in the tumor and the relative abundance of different proteins produced by the senescent cells are important biological factors that could have significant prognostic implications for the fate of the disease. The involvement in the senescent process of several oncogenes and mutations recently described in the pituitary (Vierimaa et al. 2006, Trivellin et al. 2014, Reincke et al. 2015) remains an interesting open question.

IL-6 represents an important factor in the regulation of pituitary adenoma development, as it promotes tumorigenesis by its paracrine action while restraining further proliferation by inducing and maintaining senescence in the same tumor. Which signaling pathways contribute to each action will certainly enrich the understanding of this phenomenon. Given its dual and opposite actions in the pituitary pathophysiology, IL-6 is an interesting factor for further studies in the outcome of the disease.

\section{Declaration of interest}

The authors declare that there is no conflict of interest that could be perceived as prejudicing the impartiality of this review.

\section{Funding}

Research in the authors laboratory that was discussed in this review was supported by grants from the Max Planck Society, Germany (2012/2016); the University of Buenos Aires (20020130100427); the Consejo Nacional de Investigaciones Científicas y Técnicas (D449 (01-03-2016)); the Agencia Nacional de Promoción Científica y Tecnológica, Argentina (PICT 20120431; 2014-3634; 2014-0079) and Fondo para la Convergencia Estructural de Mercosur (COF 03/11).

\section{References}

Acosta JC, O'Loghlen A, Banito A, Guijarro MV, Augert A, Raguz S, Fumagalli M, Da Costa M, Brown C, Popov N, et al. 2008 Chemokine signaling via the CXCR2 receptor reinforces senescence. Cell 133 1006-1018. (doi:10.1016/j.cell.2008.03.038)

Alexandraki KI, Munayem Khan M, Chahal HS, Dalantaeva NS, Trivellin G, Berney DM, Caron P, Popovic V, Pfeifer M, Jordan S, et al. 2012 Oncogene-induced senescence in pituitary adenomas and carcinomas. Hormones 11 297-307. (doi:10.14310/horm.2002.1358)

Ancrile B, Lim KH \& Counter CM 2007 Oncogenic Ras-induced secretion of IL6 is required for tumorigenesis. Genes and Development 21 1714-1719. (doi:10.1101/gad.1549407)
(C) 2017 Society for Endocrinology Printed in Great Britain
Published by Bioscientifica Ltd 
Andoniadou CL, Matsushima D, Mousavy Gharavy SN, Signore M, Mackintosh AI, Schaeffer M, Gaston-Massuet C, Mollard P, Jacques TS, Le Tissier P, et al. 2013 Sox2(+) stem/progenitor cells in the adult mouse pituitary support organ homeostasis and have tumorinducing potential. Cell Stem Cell 13 433-445. (doi:10.1016/j. stem.2013.07.004)

Andus T, Geiger T, Hirano T, Northoff H, Ganter U, Bauer J, Kishimoto T \& Heinrich PC 1987 Recombinant human B cell stimulatory factor 2 (BSF-2/IFN-beta 2) regulates beta-fibrinogen and albumin mRNA levels in Fao-9 cells. FEBS Letters 221 18-22. (doi:10.1016/00145793(87)80344-7)

Arzt E 2001 gp130 cytokine signaling in the pituitary gland: a paradigm for cytokine-neuro-endocrine pathways. Journal of Clinical Investigation 108 1729-1733. (doi:10.1172/JCI200114660)

Arzt E, Buric R, Stelzer G, Stalla J, Sauer J, Renner U \& Stalla GK 1993 Interleukin involvement in anterior pituitary cell growth regulation: effects of IL-2 and IL-6. Endocrinology 132 459-467. (doi:10.1210/ en.132.1.459)

Arzt E, Pereda MP, Castro CP, Pagotto U, Renner U \& Stalla GK 1999 Pathophysiological role of the cytokine network in the anterior pituitary gland. Frontiers in Neuroendocrinology 20 71-95. (doi:10.1006/frne.1998.0176)

Arzt E, Chesnokova V, Stalla GK \& Melmed S 2009 Pituitary adenoma growth: a model for cellular senescence and cytokine action. Cell Cycle 8 677-678. (doi:10.4161/cc.8.5.8065)

Baker DJ \& Sedivy JM 2013 Probing the depths of cellular senescence. Journal of Cell Biology 202 11-13. (doi:10.1083/jcb.201305155)

Barrett E, Brothers S, Wahlestedt C \& Beurel E 2014 I-BET151 selectively regulates IL-6 production. Biochimica et Biophysica Acta 1842 1549-1555. (doi:10.1016/j.bbadis.2014.05.013)

Bethin KE, Vogt SK \& Muglia LJ 2000 Interleukin-6 is an essential, corticotropin-releasing hormone-independent stimulator of the adrenal axis during immune system activation. PNAS 97 9317-9322. (doi:10.1073/pnas.97.16.9317)

Borg SA, Kerry KE, Baxter L, Royds JA \& Jones TH 2003 Expression of interleukin- 6 and its effects on growth of HP75 human pituitary tumor cells. Journal of Clinical Endocrinology and Metabolism $\mathbf{8 8}$ 4938-4944. (doi:10.1210/jc.2002-022044)

Bowman T, Garcia R, Turkson J \& Jove R 2000 STATs in oncogenesis. Oncogene 19 2474-2488. (doi:10.1038/sj.onc.1203527)

Braig M, Lee S, Loddenkemper C, Rudolph C, Peters AH, Schlegelberger B, Stein H, Dorken B, Jenuwein T \& Schmitt CA 2005 Oncogeneinduced senescence as an initial barrier in lymphoma development. Nature 436 660-665. (doi:10.1038/nature03841)

Castro CP, Giacomini D, Nagashima AC, Onofri C, Graciarena M, Kobayashi K, Paez-Pereda M, Renner U, Stalla GK \& Arzt E 2003 Reduced expression of the cytokine transducer gp130 inhibits hormone secretion, cell growth, and tumor development of pituitary lactosomatotrophic GH3 cells. Endocrinology 144 693-700. (doi:10.1210/en.2002-220891)

Chalaris A, Garbers C, Rabe B, Rose-John S \& Scheller J 2011 The soluble Interleukin 6 receptor: generation and role in inflammation and cancer. European Journal of Cell Biology 90 484-494. (doi:10.1016/j. ejcb.2010.10.007)

Chen Z, Trotman LC, Shaffer D, Lin HK, Dotan ZA, Niki M, Koutcher JA, Scher HI, Ludwig T, Gerald W, et al. 2005 Crucial role of p53dependent cellular senescence in suppression of Pten-deficient tumorigenesis. Nature 436 725-730. (doi:10.1038/nature03918)

Chesnokova V, Kovacs K, Castro AV, Zonis S \& Melmed S 2005 Pituitary hypoplasia in $\mathrm{Pttg}-/$ - mice is protective for $\mathrm{Rb}+/$ - pituitary tumorigenesis. Molecular Endocrinology 19 2371-2379. (doi:10.1210/ me.2005-0137)

Chesnokova V, Zonis S, Rubinek T, Yu R, Ben-Shlomo A, Kovacs K, Wawrowsky K \& Melmed S 2007 Senescence mediates pituitary hypoplasia and restrains pituitary tumor growth. Cancer Research 67 10564-10572. (doi:10.1158/0008-5472.CAN-07-0974)
Chesnokova V, Zonis S, Kovacs K, Ben-Shlomo A, Wawrowsky K, Bannykh S \& Melmed S 2008 p21(Cip1) restrains pituitary tumor growth. PNAS 105 17498-17503. (doi:10.1073/pnas.0804810105)

Chesnokova V, Zonis S, Zhou C, Ben-Shlomo A, Wawrowsky K, Toledano Y, Tong Y, Kovacs K, Scheithauer B \& Melmed S 2011 Lineagespecific restraint of pituitary gonadotroph cell adenoma growth. PLOS ONE 6 e17924. (doi:10.1371/journal.pone.0017924)

Cichowski K \& Hahn WC 2008 Unexpected pieces to the senescence puzzle. Cell 133 958-961. (doi:10.1016/j.cell.2008.05.027)

Clayton RN \& Farrell WE 2004 Pituitary tumour clonality revisited. Frontiers of Hormone Research 32 186-204. (doi:10.1159/000079045)

Colao A, Ochoa AS, Auriemma RS, Faggiano A, Pivonello R \& Lombardi G 2010 Pituitary carcinomas. Frontiers of Hormone Research 38 94-108. (doi:10.1159/000318499)

Collado M, Gil J, Efeyan A, Guerra C, Schuhmacher AJ, Barradas M, Benguria A, Zaballos A, Flores JM, Barbacid M, et al. 2005 Tumour biology: senescence in premalignant tumours. Nature $\mathbf{4 3 6} 642$. (doi:10.1038/436642a)

Coppe JP, Patil CK, Rodier F, Sun Y, Munoz DP, Goldstein J, Nelson PS, Desprez PY \& Campisi J 2008a Senescence-associated secretory phenotypes reveal cell-nonautonomous functions of oncogenic RAS and the p53 tumor suppressor. PLoS Biology 6 2853-2868. (doi:10.1371/journal.pbio.0060301)

Coppe JP, Boysen M, Sun CH, Wong BJ, Kang MK, Park NH, Desprez PY, Campisi J \& Krtolica A 2008b A role for fibroblasts in mediating the effects of tobacco-induced epithelial cell growth and invasion. Molecular Cancer Research 6 1085-1098. (doi:10.1158/1541-7786.MCR-08-0062)

Coppe JP, Desprez PY, Krtolica A \& Campisi J 2010 The senescenceassociated secretory phenotype: the dark side of tumor suppression. Annual Review of Pathology 5 99-118. (doi:10.1146/annurevpathol-121808-102144)

Courtois-Cox S, Genther Williams SM, Reczek EE, Johnson BW, McGillicuddy LT, Johannessen CM, Hollstein PE, MacCollin M \& Cichowski K 2006 A negative feedback signaling network underlies oncogene-induced senescence. Cancer Cell 10 459-472. (doi:10.1016/j.ccr.2006.10.003)

d'Adda di Fagagna F 2008 Living on a break: cellular senescence as a DNA-damage response. Nature Reviews Cancer 8 512-522. (doi:10.1038/nrc2440)

Darnell JE Jr 1997 STATs and gene regulation. Science 277 1630-1635. (doi:10.1126/science.277.5332.1630)

Dinarello CA 2007 Historical insights into cytokines. European Journal of Immunology 37 (Supplement 1) S34-S45. (doi:10.1002/eji.200737772)

Donangelo I, Gutman S, Horvath E, Kovacs K, Wawrowsky K, Mount M \& Melmed S 2006 Pituitary tumor transforming gene overexpression facilitates pituitary tumor development. Endocrinology $\mathbf{1 4 7}$ 4781-4791. (doi:10.1210/en.2006-0544)

Donangelo I, Ren SG, Eigler T, Svendsen C \& Melmed S 2014 Sca1(+) murine pituitary adenoma cells show tumor-growth advantage. Endocrine-Related Cancer 21 203-216. (doi:10.1530/ERC-13-0229)

Dou L, Zhao T, Wang L, Huang X, Jiao J, Gao D, Zhang H, Shen T, Man Y, Wang S, et al. 2013 miR-200s contribute to interleukin-6 (IL-6)induced insulin resistance in hepatocytes. Journal of Biological Chemistry 288 22596-22606. (doi:10.1074/jbc.M112.423145)

Dranoff G 2004 Cytokines in cancer pathogenesis and cancer therapy. Nature Reviews Cancer 4 11-22. (doi:10.1038/nrc1252)

Dworakowska D \& Grossman AB 2009 The pathophysiology of pituitary adenomas. Best Practice and Research Clinical Endocrinology and Metabolism 23 525-541. (doi:10.1016/j.beem.2009.05.004)

Dworakowska D \& Grossman AB 2012 The molecular pathogenesis of pituitary tumors: implications for clinical management. Minerva Endocrinologica 37 157-172.

Farnoud MR, Kujas M, Derome P, Racadot J, Peillon F \& Li JY 1994 Interactions between normal and tumoral tissues at the boundary of human anterior pituitary adenomas. An immunohistochemical study. Virchows Archiv 424 75-82.

Published by Bioscientifica Ltd. 
Farrell WE 2006 Pituitary tumours: findings from whole genome analyses. Endocrine-Related Cancer 13 707-716. (doi:10.1677/ erc.1.01131)

Farrell WE \& Clayton RN 1998 Molecular genetics of pituitary tumours. Trends in Endocrinology and Metabolism 9 20-26. (doi:10.1016/S10432760(98)00006-X)

Fauquier T, Rizzoti K, Dattani M, Lovell-Badge R \& Robinson IC 2008 SOX2-expressing progenitor cells generate all of the major cell types in the adult mouse pituitary gland. PNAS 105 2907-2912. (doi:10.1073/pnas.0707886105)

Florio T 2011 Adult pituitary stem cells: from pituitary plasticity to adenoma development. Neuroendocrinology 94 265-277. (doi:10.1159/000330857)

Garcia-Lavandeira M, Quereda V, Flores I, Saez C, Diaz-Rodriguez E, Japon MA, Ryan AK, Blasco MA, Dieguez C, Malumbres M, et al. 2009 A GRFa2/Prop1/stem (GPS) cell niche in the pituitary. PLoS ONE 4 e4815. (doi:10.1371/journal.pone.0004815)

Garcia-Lavandeira M, Diaz-Rodriguez E, Bahar D, Garcia-Rendueles AR, Rodrigues JS, Dieguez C \& Alvarez CV 2015 Pituitary cell turnover: from adult stem cell recruitment through differentiation to death. Neuroendocrinology 101 175-192. (doi:10.1159/000375502)

Garg M, Potter JA \& Abrahams VM 2013 Identification of microRNAs that regulate TLR2-mediated trophoblast apoptosis and inhibition of IL-6 mRNA. PLoS ONE 8 e77249. (doi:10.1371/journal.pone.0077249)

Gaston-Massuet C, Andoniadou CL, Signore M, Jayakody SA, Charolidi N, Kyeyune R, Vernay B, Jacques TS, Taketo MM, Le Tissier P, et al. 2011 Increased Wingless (Wnt) signaling in pituitary progenitor/ stem cells gives rise to pituitary tumors in mice and humans. PNAS 108 11482-11487. (doi:10.1073/pnas.1101553108)

Gerlo S, Haegeman G \& Vanden Berghe W 2008 Transcriptional regulation of autocrine IL-6 expression in multiple myeloma cells. Cellular Signalling 20 1489-1496. (doi:10.1016/j.cellsig.2008.04.004)

Gleiberman AS, Michurina T, Encinas JM, Roig JL, Krasnov P, Balordi F, Fishell G, Rosenfeld MG \& Enikolopov G 2008 Genetic approaches identify adult pituitary stem cells. PNAS 105 6332-6337. (doi:10.1073/pnas.0801644105)

Gloddek J, Pagotto U, Paez Pereda M, Arzt E, Stalla GK \& Renner U 1999 Pituitary adenylate cyclase-activating polypeptide, interleukin-6 and glucocorticoids regulate the release of vascular endothelial growth factor in pituitary folliculostellate cells. Journal of Endocrinology $\mathbf{1 6 0}$ 483-490. (doi:10.1677/joe.0.1600483)

Goel VK, Ibrahim N, Jiang G, Singhal M, Fee S, Flotte T, Westmoreland S, Haluska FS, Hinds PW \& Haluska FG 2009 Melanocytic nevus-like hyperplasia and melanoma in transgenic BRAFV600E mice. Oncogene 28 2289-2298. (doi:10.1038/onc.2009.95)

Graciarena M, Carbia-Nagashima A, Onofri C, Perez-Castro C, Giacomini D, Renner U, Stalla GK \& Arzt E 2004 Involvement of the gp130 cytokine transducer in MtT/S pituitary somatotroph tumour development in an autocrine-paracrine model. European Journal of Endocrinology 151 595-604. (doi:10.1530/eje.0.1510595)

Green MR 2008 Senescence: not just for tumor suppression. Cell 134 562-564. (doi:10.1016/j.cell.2008.08.003)

Gruys E, Toussaint MJ, Niewold TA \& Koopmans SJ 2005 Acute phase reaction and acute phase proteins. Journal of Zheijang University Science B 6 1045-1056. (doi:10.1631/jzus.2005.B1045)

Hanisch A, Dieterich KD, Dietzmann K, Ludecke K, Buchfelder M, Fahlbusch R \& Lehnert H 2000 Expression of members of the interleukin- 6 family of cytokines and their receptors in human pituitary and pituitary adenomas. Journal of Clinical Endocrinology and Metabolism 85 4411-4414. (doi:10.1210/jcem.85.11.7122)

He Y, Sun X, Huang C, Long XR, Lin X, Zhang L, Lv XW \& Li J 2014 MiR-146a regulates IL-6 production in lipopolysaccharide-induced RAW264.7 macrophage cells by inhibiting Notch1. Inflammation 37 71-82. (doi:10.1007/s10753-013-9713-0)

Heinrich PC, Behrmann I, Haan S, Hermanns HM, Muller-Newen G \& Schaper F 2003 Principles of interleukin (IL)-6-type cytokine signalling and its regulation. Biochemical Journal 374 1-20. (doi:10.1042/bj20030407)

Hirano T 2014 Revisiting the 1986 molecular cloning of interleukin 6 . Frontiers in Immunology 5 456. (doi:10.3389/fimmu.2014.00456)

Hirano T, Yasukawa K, Harada H, Taga T, Watanabe Y, Matsuda T, Kashiwamura S, Nakajima K, Koyama K, Iwamatsu A, et al. 1986 Complementary DNA for a novel human interleukin (BSF-2) that induces B lymphocytes to produce immunoglobulin. Nature $\mathbf{3 2 4}$ 73-76. (doi:10.1038/324073a0)

Hirano T, Nakajima K \& Hibi M 1997 Signaling mechanisms through gp130: a model of the cytokine system. Cytokine and Growth Factor Reviews 8 241-252. (doi:10.1016/S1359-6101(98)80005-1)

Hirano T, Ishihara K \& Hibi M 2000 Roles of STAT3 in mediating the cell growth, differentiation and survival signals relayed through the IL-6 family of cytokine receptors. Oncogene 19 2548-2556. (doi:10.1038/sj.onc.1203551)

Hodes GE, Pfau ML, Leboeuf M, Golden SA, Christoffel DJ, Bregman D, Rebusi N, Heshmati M, Aleyasin H, Warren BL, et al. 2014 Individual differences in the peripheral immune system promote resilience versus susceptibility to social stress. PNAS 111 16136-16141. (doi:10.1073/pnas.1415191111)

Hofler H, Walter GF \& Denk H 1984 Immunohistochemistry of folliculostellate cells in normal human adenohypophyses and in pituitary adenomas. Acta Neuropathologica 65 35-40. (doi:10.1007/ BF00689825)

Hosoyama T, Nishijo K, Garcia MM, Schaffer BS, Ohshima-Hosoyama S Prajapati SI, Davis MD, Grant WF, Scheithauer BW, Marks DL, et al. 2010 A postnatal Pax7 progenitor gives rise to pituitary adenomas. Genes and Cancer 1 388-402. (doi:10.1177/1947601910370979)

Hunter CA \& Jones SA 2015 IL-6 as a keystone cytokine in health and disease. Nature Immunology 16 448-457. (doi:10.1038/ni.3153)

Iwasaki H, Takeuchi O, Teraguchi S, Matsushita K, Uehata T, Kuniyoshi K, Satoh T, Saitoh T, Matsushita M, Standley DM, et al. 2011 The IkappaB kinase complex regulates the stability of cytokine-encoding mRNA induced by TLR-IL-1R by controlling degradation of regnase-1. Nature Immunology 12 1167-1175. (doi:10.1038/ni.2137)

Jiang X \& Zhang X 2013 The molecular pathogenesis of pituitary adenomas: an update. Endocrinology and Metabolism 28 245-254. (doi:10.3803/EnM.2013.28.4.245)

Jones TH, Daniels M, James RA, Justice SK, McCorkle R, Price A, KendallTaylor P \& Weetman AP 1994 Production of bioactive and immunoreactive interleukin-6 (IL-6) and expression of IL-6 messenger ribonucleic acid by human pituitary adenomas. Journal of Clinical Endocrinology and Metabolism 78 180-187. (doi:10.1210/jc.78.1.180)

Jones SA, Horiuchi S, Topley N, Yamamoto N \& Fuller GM 2001 The soluble interleukin 6 receptor: mechanisms of production and implications in disease. FASEB Journal 15 43-58. (doi:10.1096/fj.991003rev)

Jones SA, Scheller J \& Rose-John S 2011 Therapeutic strategies for the clinical blockade of IL-6/gp130 signaling. Journal of Clinical Investigation 121 3375-3383. (doi:10.1172/JCI57158)

Kim D, Pemberton H, Stratford AL, Buelaert K, Watkinson JC, Lopes V, Franklyn JA \& McCabe CJ 2005 Pituitary tumour transforming gene (PTTG) induces genetic instability in thyroid cells. Oncogene $\mathbf{2 4}$ 4861-4866. (doi:10.1038/sj.onc.1208659)

Kim DS, Franklyn JA, Smith VE, Stratford AL, Pemberton HN, Warfield A, Watkinson JC, Ishmail T, Wakelam MJ \& McCabe CJ 2007 Securin induces genetic instability in colorectal cancer by inhibiting doublestranded DNA repair activity. Carcinogenesis 28 749-759. (doi:10.1093/carcin/bgl202)

Kishimoto T 2005 Interleukin-6: from basic science to medicine - 40 years in immunology. Annual Review of Immunology 23 1-21. (doi:10.1146/annurev.immunol.23.021704.115806)

Klimpel GR 1980 Soluble factor(s) from LPS-activated macrophages induce cytotoxic $\mathrm{T}$ cell differentiation from alloantigen-primed spleen cells. Journal of Immunology 125 1243-1249. 
Kojima H, Inoue T, Kunimoto H \& Nakajima K 2013 IL-6-STAT3 signaling and premature senescence. JAK-STAT 2 e25763. (doi:10.4161/jkst.25763)

Kopczak A, Renner U \& Karl Stalla G 2014 Advances in understanding pituitary tumors. F1000Prime Reports 6 5. (doi:10.12703/P6-5)

Kovacs E 2001 Investigation of interleukin-6 (IL-6), soluble IL-6 receptor (sIL-6R) and soluble gp130 (sgp130) in sera of cancer patients. Biomedicine and Pharmacotherapy 55 391-396. (doi:10.1016/S07533322(01)00079-8)

Kraakman MJ, Kammoun HL, Allen TL, Deswaerte V, Henstridge DC, Estevez E, Matthews VB, Neill B, White DA, Murphy AJ, et al. 2015 Blocking IL-6 trans-signaling prevents high-fat diet-induced adipose tissue macrophage recruitment but does not improve insulin resistance. Cell Metabolism 21 403-416. (doi:10.1016/j. cmet.2015.02.006)

Krtolica A, Parrinello S, Lockett S, Desprez PY \& Campisi J 2001 Senescent fibroblasts promote epithelial cell growth and tumorigenesis: a link between cancer and aging. PNAS 98 12072-12077. (doi:10.1073/pnas.211053698)

Kuilman T \& Peeper DS 2009 Senescence-messaging secretome: SMS-ing cellular stress. Nature Reviews Cancer 9 81-94. (doi:10.1038/nrc2560)

Kuilman T, Michaloglou C, Vredeveld LC, Douma S, van Doorn R, Desmet CJ, Aarden LA, Mooi WJ \& Peeper DS 2008 Oncogeneinduced senescence relayed by an interleukin-dependent inflammatory network. Cell 133 1019-1031. (doi:10.1016/j. cell.2008.03.039)

Kumari N, Dwarakanath BS, Das A \& Bhatt AN 2016 Role of interleukin-6 in cancer progression and therapeutic resistance. Tumour Biology 37 11553-11572. (doi:10.1007/s13277-016-5098-7)

Lake MG, Krook LS \& Cruz SV 2013 Pituitary adenomas: an overview. American Family Physician 88 319-327.

Lazzerini Denchi E \& Helin K 2005 E2F1 is crucial for E2F-dependent apoptosis. EMBO Reports 6 661-668. (doi:10.1038/sj.embor.7400452)

Lecot P, Alimirah F, Desprez PY, Campisi J \& Wiley C 2016 Contextdependent effects of cellular senescence in cancer development. British Journal of Cancer 114 1180-1184. (doi:10.1038/bjc.2016.115)

Lee KA, Hai TY, SivaRaman L, Thimmappaya B, Hurst HC, Jones NC \& Green MR 1987 A cellular protein, activating transcription factor, activates transcription of multiple E1A-inducible adenovirus early promoters. PNAS 84 8355-8359. (doi:10.1073/pnas.84.23.8355)

Lehmann U, Schmitz J, Weissenbach M, Sobota RM, Hortner M, Friederichs K, Behrmann I, Tsiaris W, Sasaki A, Schneider-Mergener J, et al. 2003 SHP2 and SOCS3 contribute to Tyr-759-dependent attenuation of interleukin-6 signaling through gp130. Journal of Biological Chemistry 278 661-671. (doi:10.1074/jbc.M210552200)

Levy A \& Lightman S 2003 Molecular defects in the pathogenesis of pituitary tumours. Frontiers in Neuroendocrinology 24 94-127. (doi:10.1016/S0091-3022(03)00012-8)

Liu B, Liao J, Rao X, Kushner SA, Chung CD, Chang DD \& Shuai K 1998 Inhibition of Stat1-mediated gene activation by PIAS1. PNAS 95 10626-10631. (doi:10.1073/pnas.95.18.10626)

Masuda K, Ripley B, Nishimura R, Mino T, Takeuchi O, Shioi G, Kiyonari H \& Kishimoto T 2013 Arid5a controls IL-6 mRNA stability, which contributes to elevation of IL-6 level in vivo. PNAS 110 9409-9414. (doi:10.1073/pnas.1307419110)

Matsumoto H, Ishibashi Y, Ohtaki T, Hasegawa Y, Koyama C \& Inoue K 1993 Newly established murine pituitary folliculo-stellate-like cell line (TtT/GF) secretes potent pituitary glandular cell survival factors, one of which corresponds to metalloproteinase inhibitor. Biochemical and Biophysical Research Communications 194 909-915. (doi:10.1006/ bbrc.1993.1907

Matsusaka T, Fujikawa K, Nishio Y, Mukaida N, Matsushima K, Kishimoto T \& Akira S 1993 Transcription factors NF-IL6 and NF-kappa B synergistically activate transcription of the inflammatory cytokines, interleukin 6 and interleukin 8. PNAS $9010193-10197$. (doi:10.1073/pnas.90.21.10193)
McFarland-Mancini MM, Funk HM, Paluch AM, Zhou M, Giridhar PV, Mercer CA, Kozma SC \& Drew AF 2010 Differences in wound healing in mice with deficiency of IL-6 versus IL-6 receptor. Journal of Immunology 184 7219-7228. (doi:10.4049/jimmunol.0901929)

McInnes IB \& Schett G 2007 Cytokines in the pathogenesis of rheumatoid arthritis. Nature Reviews Immunology 7 429-442. (doi:10.1038/nri2094)

Melmed S 2008 Update in pituitary disease. Journal of Clinical Endocrinology and Metabolism 93 331-338. (doi:10.1210/jc.2007-1409)

Melmed S 2011 Pathogenesis of pituitary tumors. Nature Reviews Endocrinology 7 257-266. (doi:10.1038/nrendo.2011.40)

Melmed S 2015 Pituitary tumors. Endocrinology Metabolism Clinics of North America 44 1-9. (doi:10.1016/j.ecl.2014.11.004)

Mertens F, Gremeaux L, Chen J, Fu Q, Willems C, Roose H, Govaere O, Roskams T, Cristina C, Becu-Villalobos D, et al. 2015 Pituitary tumors contain a side population with tumor stem cell-associated characteristics. Endocrine-Related Cancer 22 481-504. (doi:10.1530/ erc-14-0546)

Michaloglou C, Vredeveld LC, Soengas MS, Denoyelle C, Kuilman T, van der Horst CM, Majoor DM, Shay JW, Mooi WJ \& Peeper DS 2005 BRAFE600-associated senescence-like cell cycle arrest of human naevi. Nature 436 720-724. (doi:10.1038/nature03890)

Mihara M, Hashizume M, Yoshida H, Suzuki M \& Shiina M 2012 IL-6/IL-6 receptor system and its role in physiological and pathological conditions. Clinical Science 122 143-159. (doi:10.1042/CS20110340)

Muñoz-Espín D \& Serrano M 2014 Cellular senescence: from physiology to pathology. Nature Reviews Molecular Cell Biology 15 482-496. (doi:10.1038/nrm3823)

Naka T, Narazaki M, Hirata M, Matsumoto T, Minamoto S, Aono A, Nishimoto N, Kajita T, Taga T, Yoshizaki K, et al. 1997 Structure and function of a new STAT-induced STAT inhibitor. Nature 387 924-929. (doi:10.1038/43219)

Nakajima K, Yamanaka Y, Nakae K, Kojima H, Ichiba M, Kiuchi N, Kitaoka T, Fukada T, Hibi M \& Hirano T 1996 A central role for Stat3 in IL-6-induced regulation of growth and differentiation in M1 leukemia cells. EMBO Journal 15 3651-3658.

Narita M \& Lowe SW 2005 Senescence comes of age. Nature Medicine 11 920-922. (doi:10.1038/nm0905-920)

Paez-Pereda M, Giacomini D, Refojo D, Nagashima AC, Hopfner U, Grubler Y, Chervin A, Goldberg V, Goya R, Hentges ST, et al. 2003 Involvement of bone morphogenetic protein 4 (BMP-4) in pituitary prolactinoma pathogenesis through a Smad/estrogen receptor crosstalk. PNAS 100 1034-1039. (doi:10.1073/pnas.0237312100)

Paez-Pereda M, Kuchenbauer F, Arzt E \& Stalla GK 2005 Regulation of pituitary hormones and cell proliferation by components of the extracellular matrix. Brazilian Journal of Medical and Biological Research 38 1487-1494. (doi:10.1590/S0100-879X2005001000005)

Pei L \& Melmed S 1997 Isolation and characterization of a pituitary tumor-transforming gene (PTTG). Molecular Endocrinology 11 433-441. (doi:10.1210/mend.11.4.9911)

Pereda MP, Goldberg V, Chervin A, Carrizo G, Molina A, Andrada J, Sauer J, Renner U, Stalla GK \& Arzt E 1996 Interleukin-2 (IL-2) and IL-6 regulate c-fos protooncogene expression in human pituitary adenoma explants. Molecular and Cellular Endocrinology 124 33-42. (doi:10.1016/S0303-7207(96)03924-X)

Pereda MP, Lohrer P, Kovalovsky D, Perez Castro C, Goldberg V, Losa M, Chervin A, Berner S, Molina H, Stalla GK, et al. 2000 Interleukin-6 is inhibited by glucocorticoids and stimulates ACTH secretion and POMC expression in human corticotroph pituitary adenomas. Experimental and Clinical Endocrinology and Diabetes 108 202-207. (doi:10.1055/s-2000-7887)

Perez Castro C, Nagashima AC, Pereda MP, Goldberg V, Chervin A, Largen P, Renner U, Stalla GK \& Arzt E 2000 The gp130 cytokines interleukin-11 and ciliary neurotropic factor regulate through specific receptors the function and growth of lactosomatotropic and

Published by Bioscientifica Ltd. 
folliculostellate pituitary cell lines. Endocrinology 141 1746-1753. (doi:10.1210/en.141.5.1746)

Perez Castro C, Carbia Nagashima A, Paez Pereda M, Goldberg V, Chervin A, Carrizo G, Molina H, Renner U, Stalla GK \& Arzt E 2001 Effects of the gp130 cytokines ciliary neurotropic factor (CNTF) and interleukin-11 on pituitary cells: CNTF receptors on human pituitary adenomas and stimulation of prolactin and GH secretion in normal rat anterior pituitary aggregate cultures. Journal of Endocrinology 169 539-547. (doi:10.1677/joe.0.1690539)

Perez-Castro C, Renner U, Haedo MR, Stalla GK \& Arzt E 2012 Cellular and molecular specificity of pituitary gland physiology. Physiological Reviews 92 1-38. (doi:10.1152/physrev.00003.2011)

Peters M, Jacobs S, Ehlers M, Vollmer P, Mullberg J, Wolf E, Brem G, Meyer zum Buschenfelde KH \& Rose-John S 1996 The function of the soluble interleukin 6 (IL-6) receptor in vivo: sensitization of human soluble IL-6 receptor transgenic mice towards IL- 6 and prolongation of the plasma half-life of IL-6. Journal of Experimental Medicine 183 1399-1406. (doi:10.1084/jem.183.4.1399)

Ray D \& Melmed S 1997 Pituitary cytokine and growth factor expression and action. Endocrine Reviews 18 206-228. (doi:10.1210/ edrv.18.2.0297)

Reincke M, Sbiera S, Hayakawa A, Theodoropoulou M, Osswald A, Beuschlein F, Meitinger T, Mizuno-Yamasaki E, Kawaguchi K, Saeki Y, et al. 2015 Mutations in the deubiquitinase gene USP8 cause Cushing's disease. Nature Genetics 47 31-38. (doi:10.1038/ng.3166)

Renner U, Pagotto U, Arzt E \& Stalla GK 1996 Autocrine and paracrine roles of polypeptide growth factors, cytokines and vasogenic substances in normal and tumorous pituitary function and growth: a review. European Journal of Endocrinology 135 515-532. (doi:10.1530/ eje.0.1350515)

Renner U, Gloddek J, Arzt E, Inoue K \& Stalla GK 1997 Interleukin-6 is an autocrine growth factor for folliculostellate-like TtT/GF mouse pituitary tumor cells. Experimental and Clinical Endocrinology and Diabetes 105 345-352. (doi:10.1055/s-0029-1211777)

Renner U, Gloddek J, Pereda MP, Arzt E \& Stalla GK 1998 Regulation and role of intrapituitary IL-6 production by folliculostellate cells. Domestic Animal Endocrinology 15 353-362. (doi:10.1016/S07397240(98)00027-7)

Rohleder N, Aringer M \& Boentert M 2012 Role of interleukin-6 in stress, sleep, and fatigue. Annals of the New York Academy of Sciences 1261 88-96. (doi:10.1111/j.1749-6632.2012.06634.x)

Rose-John S 2012 IL-6 trans-signaling via the soluble IL-6 receptor: importance for the pro-inflammatory activities of IL-6. International Journal of Biological Sciences 8 1237-1247. (doi:10.7150/ijbs.4989)

Rose-John S \& Heinrich PC 1994 Soluble receptors for cytokines and growth factors: generation and biological function. Biochemical Journal 300 281-290. (doi:10.1042/bj3000281)

Rose-John S, Scheller J, Elson G \& Jones SA 2006 Interleukin-6 biology is coordinated by membrane-bound and soluble receptors: role in inflammation and cancer. Journal of Leukocyte Biology 80 227-236. (doi:10.1189/jlb.1105674)

Rossato M, Curtale G, Tamassia N, Castellucci M, Mori L, Gasperini S, Mariotti B, De Luca M, Mirolo M, Cassatella MA, et al. 2012 IL-10induced microRNA-187 negatively regulates TNF-alpha, IL-6, and IL-12p40 production in TLR4-stimulated monocytes. PNAS 109 E3101-3110. (doi:10.1073/pnas.1209100109)

Ruggeri RM, Villari D, Simone A, Scarfi R, Attard M, Orlandi F, Barresi G, Trimarchi F, Trovato M \& Benvenga S 2002 Co-expression of interleukin-6 (IL-6) and interleukin-6 receptor (IL-6R) in thyroid nodules is associated with co-expression of CD30 ligand/CD30 receptor. Journal of Endocrinological Investigation 25 959-966. (doi:10.1007/BF03344068)

Sapochnik M, Haedo MR, Fuertes M, Ajler P, Carrizo G, Cervio A, Sevlever G, Stalla GK \& Arzt E 2016 Autocrine IL-6 mediates pituitary tumor senescence. Oncotarget 8 4690-4702. (doi:10.18632/ oncotarget.13577)
Scheithauer BW, Gaffey TA, Lloyd RV, Sebo TJ, Kovacs KT, Horvath E, Yapicier O, Young WF Jr, Meyer FB, Kuroki T, et al. 2006 Pathobiology of pituitary adenomas and carcinomas. Neurosurgery $\mathbf{5 9}$ 341-353; discussion 341-353. (doi:10.1227/01. NEU.0000223437.51435.6E)

Scheller J \& Rose-John S 2006 Interleukin-6 and its receptor: from bench to bedside. Medical Microbiology and Immunology 195 173-183. (doi:10.1007/s00430-006-0019-9)

Scheller J, Chalaris A, Schmidt-Arras D \& Rose-John S 2011 The pro- and anti-inflammatory properties of the cytokine interleukin-6. Biochimica et Biophysica Acta 1813 878-888. (doi:10.1016/j. bbamcr.2011.01.034)

Schett G, Elewaut D, McInnes IB, Dayer JM \& Neurath MF 2013 How cytokine networks fuel inflammation: Toward a cytokine-based disease taxonomy. Nature Medicine 19 822-824. (doi:10.1038/ nm.3260)

Simonetti S, Serrano C, Hernandez-Losa J, Bague S, Orellana R, Valverde C, Lleonart ME, Aizpurua M, Carles J, Ramon y Cajal S, et al. 2014 Schwannomas, benign tumors with a senescent phenotype. Histology and Histopathology 29 721-730. (doi:10.14670/ HH-29.721)

Spangelo BL, Judd AM, Isakson PC \& MacLeod RM 1991 Interleukin-1 stimulates interleukin-6 release from rat anterior pituitary cells in vitro. Endocrinology 128 2685-2692. (doi:10.1210/endo-128-62685)

Sparmann A \& Bar-Sagi D 2004 Ras-induced interleukin-8 expression plays a critical role in tumor growth and angiogenesis. Cancer Cell 6 447-458. (doi:10.1016/j.ccr.2004.09.028)

Spooren A, Kooijman R, Lintermans B, Van Craenenbroeck K, Vermeulen L, Haegeman G \& Gerlo S 2010 Cooperation of NFkappaB and CREB to induce synergistic IL-6 expression in astrocytes. Cellular Signalling 22 871-881. (doi:10.1016/j. cellsig.2010.01.018)

Starr R, Willson TA, Viney EM, Murray LJ, Rayner JR, Jenkins BJ, Gonda TJ, Alexander WS, Metcalf D, Nicola NA, et al. 1997 A family of cytokine-inducible inhibitors of signalling. Nature 387 917-921. (doi:10.1038/43206)

Sun Y, Sun J, Tomomi T, Nieves E, Mathewson N, Tamaki H, Evers R \& Reddy P 2013 PU.1-dependent transcriptional regulation of miR-142 contributes to its hematopoietic cell-specific expression and modulation of IL-6. Journal of Immunology 190 4005-4013. (doi:10.4049/jimmunol.1202911)

Tichomirowa M, Theodoropoulou M, Lohrer P, Schaaf L, Losa M, Uhl E, Lange M, Arzt E, Stalla GK \& Renner U 2005 Bacterial endotoxin (lipopolysaccharide) stimulates interleukin-6 production and inhibits growth of pituitary tumour cells expressing the toll-like receptor 4 . Journal of Neuroendocrinology 17 152-160. (doi:10.1111/j.1365-2826.2005.01286.x)

Trivellin G, Daly AF, Faucz FR, Yuan B, Rostomyan L, Larco DO, Schernthaner-Reiter MH, Szarek E, Leal LF, Caberg JH, et al. 2014 Gigantism and acromegaly due to Xq26 microduplications and GPR101 mutation. New England Journal of Medicine 371 2363-2374. (doi:10.1056/NEJMoa1408028)

Ueta Y, Levy A, Chowdrey HS \& Lightman SL 1995 S-100 antigenpositive folliculostellate cells are not the source of IL-6 gene expression in human pituitary adenomas. Journal of Neuroendocrinology 7 467-474. (doi:10.1111/j.1365-2826.1995. tb00783.x)

Vajtai I, Kappeler A \& Sahli R 2007 Folliculo-stellate cells of 'true dendritic' type are involved in the inflammatory microenvironment of tumor immunosurveillance of pituitary adenomas. Diagnostic Pathology 2 20. (doi:10.1186/1746-1596-2-20)

Vandeva S, Jaffrain-Rea ML, Daly AF, Tichomirowa M, Zacharieva S \& Beckers A 2010 The genetics of pituitary adenomas. Best Practice and Research Clinical Endocrinology and Metabolism 24 461-476. (doi:10.1016/j.beem.2010.03.001) 
Vankelecom H \& Gremeaux L 2010 Stem cells in the pituitary gland: A burgeoning field. General and Comparative Endocrinology 166 478-488. (doi:10.1016/j.ygcen.2009.11.007)

Vankelecom H, Carmeliet P, Van Damme J, Billiau A \& Denef C 1989 Production of interleukin- 6 by folliculo-stellate cells of the anterior pituitary gland in a histiotypic cell aggregate culture system. Neuroendocrinology 49 102-106. (doi:10.1159/000125097)

Ventura A, Kirsch DG, McLaughlin ME, Tuveson DA, Grimm J, Lintault L, Newman J, Reczek EE, Weissleder R \& Jacks T 2007 Restoration of p53 function leads to tumour regression in vivo. Nature $\mathbf{4 4 5}$ 661-665. (doi:10.1038/nature05541)

Vierimaa O, Georgitsi M, Lehtonen R, Vahteristo P, Kokko A, Raitila A, Tuppurainen K, Ebeling TM, Salmela PI, Paschke R, et al. 2006 Pituitary adenoma predisposition caused by germline mutations in the AIP gene. Science 312 1228-1230. (doi:10.1126/science.1126100)

Vizioli MG, Santos J, Pilotti S, Mazzoni M, Anania MC, Miranda C, Pagliardini S, Pierotti MA, Gil J \& Greco A 2014 Oncogenic RASinduced senescence in human primary thyrocytes: molecular effectors and inflammatory secretome involved. Oncotarget 5 8270-8283. (doi:10.18632/oncotarget.2013)

Vlotides G, Eigler T \& Melmed S 2007 Pituitary tumor-transforming gene: physiology and implications for tumorigenesis. Endocrine Reviews 28 165-186. (doi:10.1210/er.2006-0042)

Wolf J, Rose-John S \& Garbers C 2014 Interleukin-6 and its receptors: a highly regulated and dynamic system. Cytokine 70 11-20. (doi:10.1016/j.cyto.2014.05.024)

Woloski BM \& Fuller GM 1985 Identification and partial characterization of hepatocyte-stimulating factor from leukemia cell lines: comparison with interleukin 1. PNAS 82 1443-1447. (doi:10.1073/pnas.82.5.1443)

Xiang M, Birkbak NJ, Vafaizadeh V, Walker SR, Yeh JE, Liu S, Kroll Y, Boldin M, Taganov K, Groner B, et al. 2014 STAT3 induction of miR$146 \mathrm{~b}$ forms a feedback loop to inhibit the NF-kappaB to IL-6 signaling axis and STAT3-driven cancer phenotypes. Science Signaling 7 ra11. (doi:10.1126/scisignal.2004497)

Xue W, Zender L, Miething C, Dickins RA, Hernando E, Krizhanovsky V, Cordon-Cardo C \& Lowe SW 2007 Senescence and tumour clearance is triggered by p53 restoration in murine liver carcinomas. Nature 445 656-660. (doi:10.1038/nature05529)

Yang X, Liang L, Zhang XF, Jia HL, Qin Y, Zhu XC, Gao XM, Qiao P, Zheng Y, Sheng YY, et al. 2013 MicroRNA-26a suppresses tumor growth and metastasis of human hepatocellular carcinoma by targeting interleukin-6-Stat3 pathway. Hepatology 58 158-170. (doi:10.1002/hep.26305)

Yao X, Huang J, Zhong H, Shen N, Faggioni R, Fung M \& Yao Y 2014 Targeting interleukin- 6 in inflammatory autoimmune diseases and cancers. Pharmacology and Therapeutics 141 125-139. (doi:10.1016/j. pharmthera.2013.09.004)

Yasukawa K, Hirano T, Watanabe Y, Muratani K, Matsuda T, Nakai S \& Kishimoto T 1987 Structure and expression of human B cell stimulatory factor-2 (BSF-2/IL-6) gene. EMBO Journal 6 2939-2945.

Yoshida K, Taga T, Saito M, Suematsu S, Kumanogoh A, Tanaka T, Fujiwara H, Hirata M, Yamagami T, Nakahata T, et al. 1996 Targeted disruption of gp130, a common signal transducer for the interleukin 6 family of cytokines, leads to myocardial and hematological disorders. PNAS 93 407-411. (doi:10.1073/pnas.93.1.407)

Yoshizaki K, Nakagawa T, Fukunaga K, Tseng LT, Yamamura Y \& Kishimoto T 1984 Isolation and characterization of B cell differentiation factor (BCDF) secreted from a human B lymphoblastoid cell line. Journal of Immunology 132 2948-2954.

Young AR, Narita M, Ferreira M, Kirschner K, Sadaie M, Darot JF, Tavare S, Arakawa S, Shimizu S, Watt FM, et al. 2009 Autophagy mediates the mitotic senescence transition. Genes and Development $\mathbf{2 3}$ 798-803. (doi:10.1101/gad.519709)

Young AR, Narita M \& Narita M 2013 Cell senescence as both a dynamic and a static phenotype. Methods in Molecular Biology 965 1-13. (doi:10.1007/978-1-62703-239-1_1)

Yu R \& Melmed S 2010 Pathogenesis of pituitary tumors. Progress in Brain Research 182 207-227. (doi:10.1016/S0079-6123(10)82009-6)

Yu H, Pardoll D \& Jove R 2009 STATs in cancer inflammation and immunity: a leading role for STAT3. Nature Reviews Cancer $\mathbf{9}$ 798-809. (doi:10.1038/nrc2734)

Yun UJ, Park SE, Jo YS, Kim J \& Shin DY 2012 DNA damage induces the IL-6/STAT3 signaling pathway, which has anti-senescence and growth-promoting functions in human tumors. Cancer Letters 323 155-160. (doi:10.1016/j.canlet.2012.04.003)

Zhang X, Horwitz GA, Prezant TR, Valentini A, Nakashima M, Bronstein MD \& Melmed S 1999 Structure, expression, and function of human pituitary tumor-transforming gene (PTTG). Molecular Endocrinology 13 156-166. (doi:10.1210/mend.13.1.0225)

Zhang T, Zhao B, Li J, Zhang C, Li H, Wu J, Zhang S \& Hui G 2015 Pituitary gene expression differs in D-galactose-induced cell senescence and steroid-induced prolactinomas. Molecular Medicine Reports 11 3027-3032. (doi:10.3892/mmr.2014.3062)

Received in final form 28 March 2017

Accepted 5 April 2017

Accepted Preprint published online 5 April 2017
(C) 2017 Society for Endocrinology Printed in Great Britain
Published by Bioscientifica Ltd. 